\title{
OBLIQUE AND NOMINATIVE NOMINAL POSSESSORS IN FOREST ENETS
}

\author{
Maria Ovsjannikova \\ Institute for Linguistic Studies RAS, St. Petersburg
}

\begin{abstract}
Two types of possessor encoding are distinguished in Forest Enets, the nominative and the oblique. Elicited data show that the oblique possessor is a part of the noun phrase headed by the possessee, whereas the nominative possessor shows the properties both of a detached topicalized constituent and of an external possessor. The main focus of the study is on the use of these strategies in texts. I examine their distribution in terms of the syntactic function and semantic class of the possessee and the predicate type. The nominative possessor encoding is shown to be strongly associated with constructions that describe 1) various types of possessive relations (predicating possession, stating the possessor's age and name) and 2) the state of the possessor's body part. Oblique possessors typically serve as referential anchors and are less determined by constructional semantics, in particular they are more common when the possessee is agentive and animate.
\end{abstract}

Keywords: possession, topic, predicative possessive construction, Enets, external possessor, nominative possessor

DOI: https://doi.org/10.12697/jeful.2020.11.2.03

\section{Introduction}

This paper is concerned with the grammatical encoding of possessors in Enets, a highly endangered language of the Samoyedic branch of the Uralic language family. Enets is spoken by no more than 50 speakers in the North of Krasnoyarsk Krai in Central Siberia, Russia. Enets has two dialects, Forest and Tundra. This paper is based on the data of the Forest dialect, which has more speakers and a larger text corpus. The Tundra dialect has the same inventory of possessor encoding strategies, and they seem to be similarly distributed in texts, but the data of this dialect will not be analysed due to their scarcity.

The goal of this study is to establish the major strategies of possessor encoding in Enets and to investigate the use of these strategies in Enets 
texts. This paper will deal with the encoding of nominal possessors, as in (1)-(2) (possessors in these examples and below are in bold). Pronominal possessors display a different set of encoding strategies that deserve a separate treatment and will be discussed elsewhere.

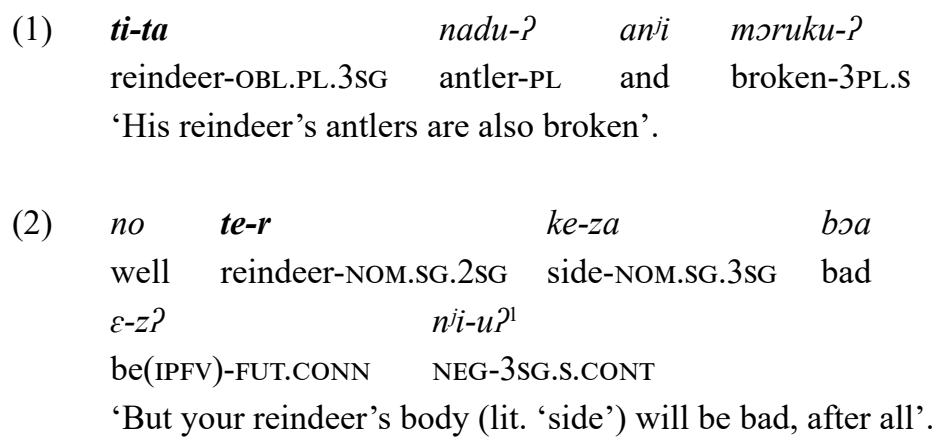

Examples (1)-(2) illustrate the two strategies of nominal possessor encoding that will be discussed in this paper, the oblique (1) and the nominative (2) possessor encoding. The major part of this paper will be concerned with the syntactic differences between these strategies and their distribution in Enets texts.

This study is mainly based on the data taken from the corpus of glossed texts in Forest Enets (115 000 words, ca. 25 hours) ${ }^{2}$. Some generalizations will also be made using elicited data collected in the summers of 2009-2010 and 2015-2016 in the village of Potapovo in the Taymyrsky Dolgano-Nenetsky District of Krasnoyarsk Krai. The

1 The clauses containing the negative verb with contrastive agreement markers have affirmative reading and are generally used to mark statements that are evidently true. This pragmatic effect is absent only in the clauses with the verb man 'say' - then it serves simply to introduce direct speech. See (Šluinskij 2010) on the morphology and functions of these agreement markers.

2 The corpus used for this study contains the texts recorded and transcribed by Andrey Shluinsky, Olesya Khanina, the author, Natasha Stoynova and Sergey Trubetskoy in 2005-2010; legacy recordings, kindly provided by the Dudinka branch of GTRK 'Noril'sk', Tajmyr House of Folk Culture, Dar'ja S. Bolina, Oksana E. Dobzhanskaja, Irina P. Sorokina, and Anna Ju. Urmanchieva, transcribed in 2005-2010 by the people mentioned above and glossed by Andrey Shluinsky. In 2005-2010 the work was conducted as a part of the project «Documentation of Enets: digitization and analysis of legacy field materials and fieldwork with last speakers» supported by the Endangered Languages Documentation Programme, SOAS, University of London. 
examples taken from the elicited data are indicated by an abbreviation "(elic.)".

The remainder of the paper is organized as follows. In Section 2, I discuss the theoretical background of the study and its objectives. Section 3 gives an overview of Enets case marking and of the possessor encoding strategies under study. In Section 4, I discuss the structural properties of these strategies. In Section 5, I examine the use of the two types of possessor encoding in texts. In Section 6, the results of the study are compared to existing accounts of possessive constructions in other Samoyedic languages and discussed in a wider typological perspective. Section 7 summarizes the main conclusions.

\section{Theoretical background and objectives}

One of the major typological distinctions in the domain of possession is between predicative and attributive possessive constructions (Heine 1997: 25-29, Herslund and Baron 2001: 4). In predicative possessive constructions, the possessive relation is asserted, as in (3), while in attributive possessive constructions it is presupposed (4).

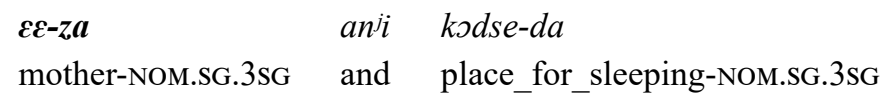

'And her mother had bed-curtains, after all'.

$\begin{array}{lll}\varepsilon \varepsilon-d a & \text { ubaj } & \text { koa } \\ \text { mother-OBL.SG.3SG } & \text { thimble } & \text { find(PFV).3sG.S }\end{array}$

'She found her mother's thimble'.

In this paper, the distinction between predicative and attributive possession will be understood in purely semantic terms. In particular, qualifying a possessive constructions as an attributive one does not imply that the possessor performs the syntactic function of an attribute, i. e. belongs to the noun phrase headed by the possessee. Likewise, predicative possessive construction is understood simply as a means of predicating possession, with no specific syntactic status attached to it. 
Predicative possession can indeed often be opposed to attributive possession not only in semantic but also in syntactic terms. Even in the languages where the same possessor encoding strategy is attested in both of these domains, the syntactic status of the possessor is claimed to be different in that in predicative possessive constructions it shows more syntactic independence than in the domain of attributive possession (cf. Stassen 2009: 113-122).

Under the approach taken in this study, the distinction between predicative and attributive possession is only one of the distinctions that can be drawn in the semantic domain of possession. In Enets, there is no specific way of possessor encoding found only in the predicative possessive construction, therefore there is no reason to treat it separately a priori. The analysis takes as its departure point the distinction between two types of possessor encoding introduced above, i.e. the nominative and the oblique possessor. Then I proceed bottom-up by examining the syntactic properties of the two types of possessors and their use in texts in terms of possessee types, predicate types and, more generally, construction types, including the predicative possessive construction. Finally, I propose a unifying analysis that relates the syntactic properties of the possessors to the semantic features of clauses and the types of constructions they are associated with.

On the syntactic side, the distinction may be drawn between internal, or adnominal possessors, which are inside the possessee noun phrase, and external possessors, which are clause-level constituents outside of the possessee noun phrase (see König and Haspelmath 1997, Payne and Barshi 1999, among others). In addition to these two syntactic types of possessors, for the nominative possessor I will consider the possibility of the analysis in terms of a detached topicalized constituent (cf. Lambrecht 1994: 182). While the topic will be understood as a discourse status that reflects the referent's importance in the preceding and following context and has no direct correspondence in syntax, the detachment will be considered a syntactic mechanism that leads to the expression of a referent outside the clause it is related to.

Thus, the overall objective of the study is to situate the two possessor encoding strategies in Enets relative to the syntactic types of possessors and determine the semantic and pragmatic conditions of their use. 


\section{Case marking and possessor encoding in Enets: an overview}

The Enets case system can be subdivided into core and spatial cases, and the number of cases distinguished in each of these subsystems varies. In this paper, I will distinguish between two core cases, nominative and oblique, following Xanina and Šluinskij (2013), and four spatial cases. There are some differences in the case paradigms of nouns used with and without possessive markers and traditionally, case forms are described separately for the so-called possessive and non-possessive declensions.

In the non-possessive declension, the number of formally distinct core case forms and the choice of case allomorphs depends on the inflectional class of the noun, which is determined by the stem type. The major distinction here is between default and (several) non-default inflectional classes.

Table 1 gives the case forms for the two types of declension and, in the non-possessive declension, for the nouns of different inflectional classes. It shows the possessive paradigm for the noun kado 'sledge' and the non-possessive paradigm for the same noun and for the noun $m \varepsilon$ ? 'chum', which belong to the default and one of the non-default inflectional classes, respectively. The noun in the possessive declension is given with the markers for a 3rd person singular possessor and a singular possessee. The morphemic border between the stem, the case marker and the possessive marker is indicated.

Table 1. Case marking of Enets nouns

\begin{tabular}{|c|c|c|c|}
\hline & \multirow{2}{*}{$\begin{array}{l}\text { Possessive } \\
\text { declension }\end{array}$} & \multicolumn{2}{|c|}{ Non-possessive declension } \\
\hline & & Default class & Non-default class \\
\hline Nominative & $k \supset d o-z a$ & kodo & $m \varepsilon ?$ \\
\hline Oblique & $k \supset d o-d a$ & kədo & $m \varepsilon z u$ \\
\hline Dative & $k \supset d o-x o-d a$ & $k \supset d o-d$ & $m \varepsilon-t$ \\
\hline Locative & kodo-xon-da & kədo-xon & $m \varepsilon-k o n$ \\
\hline Ablative & kodo-xoz-da & kədo-xoz & $m \varepsilon-k o z$ \\
\hline Prolative & $k \supset d o-\supset n-d a$ & kədo-sn & $m \varepsilon z u-\supset n$ \\
\hline
\end{tabular}


As mentioned above, Enets nominal possessors can be encoded either by the nominative or by the oblique case. Therefore, I will discuss these two case forms in more detail, focusing on their morphological distinguishability and syntactic distribution.

In the possessive declension, the nominative and oblique case forms are formally distinct in all but three cells of the paradigm, namely when the possessee is plural and the possessor is 1st person singular, dual or plural. The syntactic distribution of Enets core case forms in the possessive declension is rather complex and has received various analyses in the literature, see Xanina and Šluinskij 2013 for an overview. Table 2 shows the possessive markers for a singular possessor used for a singular possessee in the syntactic positions of subject, direct object and adnominal (and postpositional) dependent. The allomorphs used with the nouns of the defaul inflectional class are given. The grey cells contain the markers that are used in oblique case forms.

Table 2. Possessive markers for a singular possessor and a singular possessee across core syntactic functions

\begin{tabular}{cccc}
\hline $\begin{array}{c}\text { Possessor } \\
\text { person }\end{array}$ & Subject & Direct object & $\begin{array}{c}\text { Adnominal } \\
\text { dependent }\end{array}$ \\
\hline 1 & $-j ?,-b i$ ? & $-j ?,-b i$ ? & $-n^{j i} i$ \\
2 & $-r$ & $-d$ & $-d$ \\
3 & $-z a$ & $-d a$ & $-d a$ \\
\hline
\end{tabular}

Table 2 shows that in this part of the possessive declension, for the 1st person possessors, subjects and direct objects have the same marking and for the possessors of the other two persons, the marking of direct objects and adnominal (and postpositional) dependent coincide. Due to this distribution of markers across syntactic functions, most grammatical descriptions of Enets distinguish between three core cases, i.e. nominative, accusative and genitive, depending on the syntactic function (Tereščenko 1966, Siegl 2013: 125, 151-152). In this paper, I adopt the analysis proposed by Xanina and Šluinskij (2013), whereby two core cases are distinguished for Enets, nominative and oblique, without the direct mapping of cases to core syntactic functions.

In the non-possessive declension, as shown in Table 1, the nouns of the default inflectional class, which constitute the majority of Enets 
nouns, do not have distinct forms of the nominative and oblique cases ${ }^{3}$. For the nouns of this class, the same bare stem is used for the subject, adnominal modifier and direct object functions. Thus, the nouns of the default inflectional class without possessive markers do not have formally distinct forms of nominative and oblique cases. Still, although non-overt, the distinction between the two core cases will be drawn for these nouns as well.

Finally, for the nouns of non-default inflectional classes, the nominative and the oblique cases can be distinguished as these nouns have two stems, the nominative and the oblique. The nominative stem is used in the singular form of the nominative case. The oblique stem is used as an oblique case form and it combines with other suffixes to build the other forms of the nominal paradigm (sometimes reflected in the choice of an affix allomorph).

Turning to the strategies of possessor marking, both the nominative and the oblique cases are employed in this domain (5)-(6).

$\begin{array}{lllll}\text { kodo-n } \boldsymbol{n} \boldsymbol{i} \boldsymbol{i} \text { r } & \text { puja } & \text { t/ike } & \text { nəru? } & \text { mərji } \\ \text { sledge-OBL.SG.1SG } & \text { nose } & \text { this } & \text { across } & \text { break(PFV).3sG.S }\end{array}$

'The nose of my sledge crushed by this'.
tjike kodo-r
puja-za
diagoma $^{4}$
this sledge-NOM.SG.2SG
nose-NOM.SG.3sG
be absent.INC.3sG.S
'The nose of this sledge has been lost'.

The oblique encoding is well documented in the grammars and can be viewed as the default possessor marking strategy. By contrast, the nominative marking is not documented in the existing grammatical descriptions of Enets (Sorokina 2010, Siegl 2013), although it is mentioned in the discussions of possessive constructions in Samoyedic in general (Honti 2008: 165-166, Wagner-Nagy 2011: 237-240), see Section 6.1 for details.

\footnotetext{
3 Diachronically, the nominative and oblique cases were formally distinct, and the glottal stop was used as a marker of the oblique case, cf. Tereščenko 1966 (this distinction is still marginally present in the Tundra dialect). Nowadays, the glottal stop in the oblique case is almost completely lost.

4 The 2 nd person possessive marker on the possessor in (6) is used in a discourse-oriented function related to participant topicality (cf. Siegl 2015).
} 
As follows from the discussion above, the nominative and the oblique possessors are formally distinct in most cases when the possessor bears a possessive marker, as in (5)-(6) above, or, in the nonpossessive declension, when the noun expressing the possessor belongs to the non-default inflectional class, as in (7)-(8).

\begin{tabular}{|c|c|c|c|}
\hline $\begin{array}{l}\text { te } \\
\text { reindeer }\end{array}$ & osn $i-d a$ & $\begin{array}{l}\text { entfeu } \\
\text { person } \mathrm{OBL}\end{array}$ & $\begin{array}{l}\text { moza?a } \\
\text { work }\end{array}$ \\
\hline sojza-an & tcne-za & & \\
\hline good-PROL.SC & know(IPFV) & S.SO.SG & \\
\hline
\end{tabular}

'He knows well the work of a person looking after reindeer'.

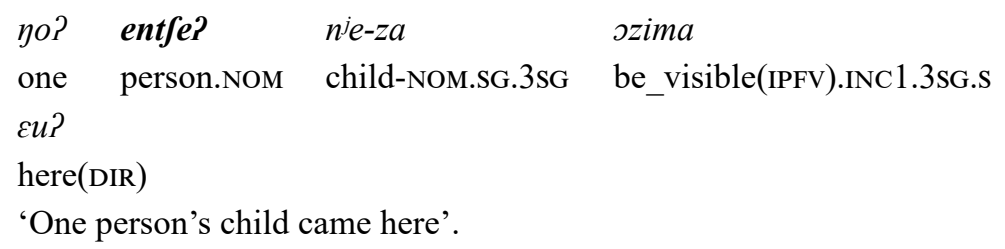

When the possessor is expressed by a noun of the default inflectional class without possessive markers the type of possessor encoding cannot be determined on the basis of the form of the possessor (9)-(10).

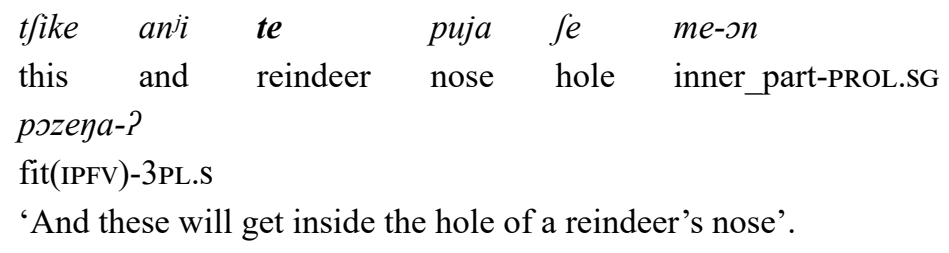

Still, as the examples (5)-(8) show, the two types of possessor encoding consistently differ in terms of the possessee marking. In clauses with oblique possessors (5), (7), there is usually no possessive marking on the possessee, although some speakers judged the use of a possessive marker on the possessee as acceptable. In clauses with nominative possessors (6), (8), the possessor is obligatorily cross-referenced on the possessee. Thus, even when the case form of the possessor is not 
overtly marked, the cross-referencing of the possessor on the possessee was used as a cue to the type of the encoding: examples without possessive marking on the possessee were considered as clauses with oblique possessors (9), examples with possessive marking on the possessee were classified as instances of the nominative possessor encoding (10).

\section{Syntactic properties of clauses with nominative and oblique possessors}

This section deals with the syntactic properties of the two types of possessor encoding strategies that can be presumably viewed as categorical rather than statistical. Most of these properties were already discussed by Ovsjannikova $(2011,2018)$, based mainly on elicited data.

First, on the basis of elicited data, it was shown that the nominative possessor, unlike the oblique possessor, can be separated from the possessee by clause-level constituents. The corpus data confirm this generalization, cf. (11)-(12), where the nominative possessor is separated from the possessee by constituents that cannot be analysed as parts of the noun phrase headed by the possessee.

\begin{tabular}{|c|c|c|c|}
\hline $\begin{array}{l}\text { su, } \\
\text { EXC }\end{array}$ & $\begin{array}{l}\text { t/ike-r } \\
\text { this-NOM.SG.2SG }\end{array}$ & $\begin{array}{l}\text { toxaz? } \\
\text { and now }\end{array}$ & $\begin{array}{l}s \varepsilon j u-z a \\
\text { heart-NOM.SG.3sG }\end{array}$ \\
\hline$n^{j i} i-u ?$ & $m \supset z$ & & \\
\hline JEG- & .S.CONT & move(P & $-\mathrm{CONN}$ \\
\hline
\end{tabular}

'Oh, now this one's heart indeed faltered' \{when he saw a woman\}.

$\begin{array}{lllll}\varepsilon t f u j-? & \text { teza? } & m u t f i-d u ? & \text { torse } & n^{i i-u} \\ \text { child-PL } & \text { now } & \text { custom-NOM.SG.3PL } & \text { such } & \text { NEG-3SG.S.CONT } \\ \eta a-? & & & \\ \text { be(IPFV)-CONN } & \\ \text { 'Nowadays children's customs are this way'. }\end{array}$

The two types of possessors also differ in their linear position relative to modifiers of the possessee. Oblique possessors can be preceded by some other types of modifiers, for instance, in (13) the demonstrative pronoun tfike 'this' precedes the possessor 'lad'. Nominative possessors always precede all the modifiers of the possessee (14). 
66 Maria Ovsjannikova

(13)

$\begin{array}{lllll}\text { tfike } & \text { kasa } & \text { ctfe-d } & \text { sse } & \text { mana } \\ \text { this } & \text { man } & \text { child-OBL.SG.2SG } & \text { father } & \text { say(PFV).3sG.s }\end{array}$

'That father of the lad says'.

(14)

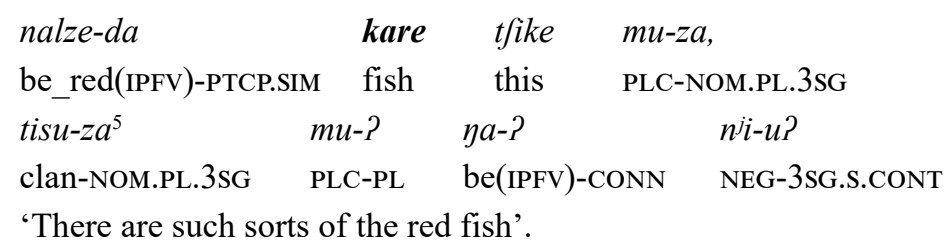

Another syntactically relevant property of the nominative possessor is that the possessee can be omitted under ellipsis (15) and pronominalized (16). By contrast, in clauses with oblique possessors the pronominalization of the possessee was not allowed by the consultants, $\mathrm{cf}$. the pair of elicited examples in (17)-(18).

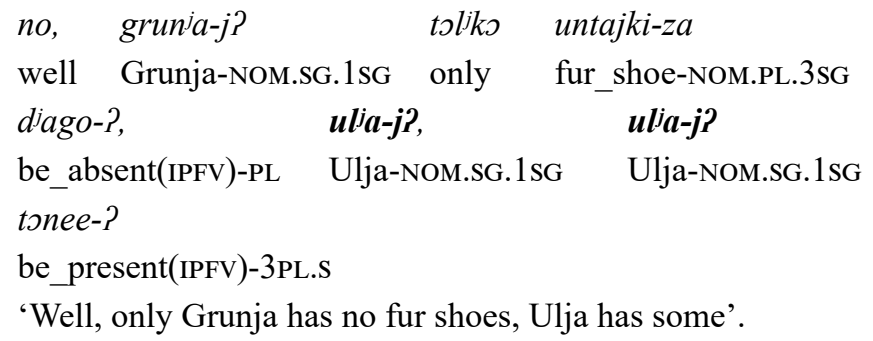

'And the other one has nothing aching'.

\footnotetext{
5 The speaker first uses the placeholder $m u$ as the possessee but then replaces it with the noun tisu 'clan'.

6 In example (16), the encoding of the possessor nckuju 'the other' cannot be determined on the basis of morphological marking. Still, as discussed in Section 3, the possessor is presumably in the nominative case, as indicated by the presence of a possessive marker on the possessee sbuxuru 'nothing', which in this case stands for 'no body part'.
} 


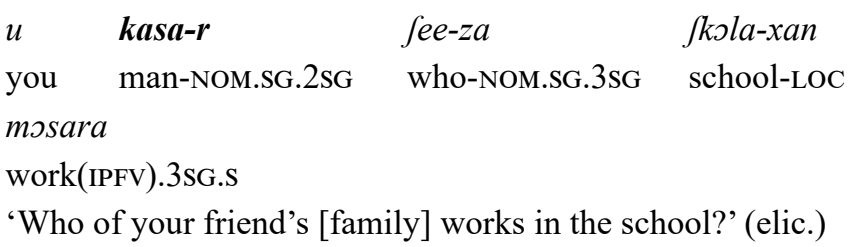

$\begin{array}{llccc}* u & \text { kasa-d } & \text { fee } & \text { Jksla-xan } & \text { mosara } \\ \text { you } & \text { man-OBL.SG.2sG } & \text { who } & \text { school-LOC } & \text { work(IPFV).3sG.S } \\ \text { Intended: 'Who of your friend's [family] works in the school?' (elic.) }\end{array}$

These syntactic properties of the nominative possessor indicate that it does not form a single noun phrase with the possessee, see König and Haspelmath (1997: 527-528) on the separability and pronominalization as criteria of constituency discussed specifically for possessive constructions. The oblique possessor, on the contrary, behaves as a part of the noun phrase headed by the possessee.

The grammatical properties of the nominative possessor suggest that it is related to possessor topicalization, as has been already proposed by Ovsjannikova (2011, 2018). According to Heine (1997), constructions of the type "(As for) X, X's Y" with a topicalized detached possessor are one of the wide-spread sources for possessive constructions. The obligatory use of cross-referencing possessive marker on the possessee (observed in the Enets clauses with nominative possessors) is typical both for constructions with a detached topicalized constituent (cf. Lambrecht 1994: 182) and possessive constructions developing from them (Heine 1997: 159, Stassen 2009: 71). The possibility of separation of the possessor and the possessee is also expected given the low degree of integration between the possessor and possessee in the source construction.

Although the nominative possessor retains some of the features indicative of its origin, it seems to be no longer a result discoursetriggered topicalization as such. This view is supported by some syntactic properties of the nominative possessors. First, the nominative encoding of possessor is possible in subordinate clauses (cf. Ovsjannikova 2018: 64), which generally are expected to show restrictions on topicalization and other pragmatically motivated constructions (cf. Bybee 2001: 1-2, Matić et al. 2014: 13-18). Second, the nominative possessor can be expressed by interrogative and negative pronouns, $\mathrm{cf}$. (19)-(20), which can hardly serve as topics. 


$\begin{array}{lll}\text { fee } \quad \text { oo- } d a & m u-z u ? & \text { tonee-sa } \\ \text { who eat(IPFV)-PTCP.SIM } & \text { PLC-NOM.PL.3PL } & \text { be_present(IPFV)-Q.3sG.S } \\ \text { vot } & & \\ \text { here } & & \\ \text { 'Who had food?' } & \end{array}$

\footnotetext{
ku-kuru-ba?

bii-da

u? te-xan

where-EVEN-NOM.SG.1PL mind-OBL.SG.3SG mind reindeer-LOC.SG $n^{i} i \quad \eta a-?$

NEG.3SG.S be(IPFV)-CONN

'None of us has thoughts directed towards the reindeer' (= 'doesn't think about the reindeer').
}

To sum up, while the oblique possessor manifests all the properties of a well-behaved internal possessor, the nominative possessors are likely to be clause-level constituents that are external to the noun phrase headed by the possessee. Another possibility is that the nominative possessor can both be a detached topicalized constituent, which is clause-external, and an external clause-level constituent, depending on the type of context. Still, for the majority of corpus examples, there is no way to distinguish between these two analyses and from the theoretical perspective, the latter is more remarkable. For this reason, the nominative possessor in all its uses will be regarded here as a clause-level external possessor.

In Section 5, I focus on the use of the nominative and the oblique possessor encoding strategies in texts. Section 5.1 sets the stage for the corpus study of the two encoding strategies and defines its scope. Sections 5.2 and 5.3 discuss the syntactic behavior of the two types of possessors, viz. their linear position in examples from the texts and the syntactic function of their possessees. In Sections 5.4 and 5.5 I turn to the semantic distribution of the two encoding strategies and compare them in terms of the semantic class of the possessee and the type of the predicate. As the oblique possessor encoding is the default strategy well-attested in the descriptions, it will serve as the background for the analysis of the less studied and more grammatically unusual nominative possessors. 


\section{Encoding of nominal possessors in texts}

\subsection{Data for the corpus-study: human participants as prototypical possessors}

The nominative and oblique case forms that are distinguished for possessors are the two case forms also used to encode subjects and direct objects. This makes extraction of the possessors from texts difficult and time-consuming. Therefore, practically the analysis of the two possessor encoding strategies is mainly based on a sample containing the possessive uses of the nouns that are likely to perform the function of a possessor.

It is well-known that typical possessors are human or at least animate (Seiler 1983: 4, Aikhenvald 2013: 11). In Enets there are no semantic restrictions on the semantic class of possessor neither for the nominative, nor for the oblique possessor encoding. Still, it is expected that human nouns are more frequently used as possessors than non-human animate nouns, and particularly more frequently than inanimate nouns. Specifically, for a number of high-frequency nouns denoting humans the uses in the role of the possessor were manually extracted from the texts in Forest Enets. These nouns were buuse 'old man, husband', disi 'grandfather', $\varepsilon \varepsilon$ 'mother', $\varepsilon d i u k u$ 'child', $\varepsilon n t f e$ ? 'person', $\varepsilon s e$ 'father', ctfe 'child', kasa 'man, sibling', kaza 'grandmother', mense 'old woman, wife', $n^{j} e$ 'child', $n \varepsilon$ 'woman'. Many of these nouns are kinship terms or can be used as such, cf. (21) with the noun buuse 'old man' used in the meaning 'husband'. As kinship terms are relational nouns, they are often marked with possessive suffixes, and the presence of the latter makes the identification of the type of possessor encoding more straight-forward, see Section 2.

$\begin{array}{llll}a \quad \text { buuse-nij? } & \varepsilon \varepsilon-k u j i & \begin{array}{l}\text { man-? } \\ \text { and old_man-OBL.SG.1SG }\end{array} \\ n^{i} i \text { - } u \text { ? } & & & \\ \text { NEG-3SG.S.CONT } & & \end{array}$

'And my husband's deceased mother said'.

As the result of the described procedure, a sample of 292 examples was established. It contains 215 examples of the oblique possessor encoding (21) and 77 examples of the nominative possessor encoding 
(22). It is this sample that was used to quantitatively assess the differences between the two types of encoding of nominal possessors.

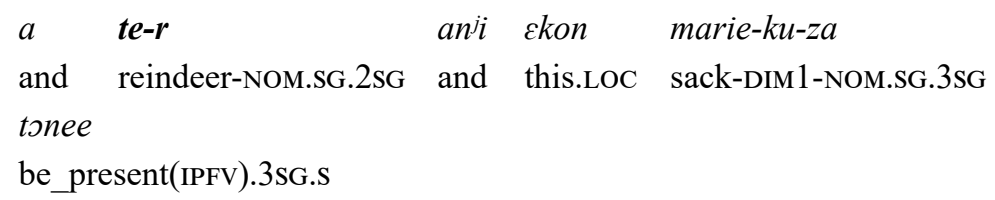

'And a reindeer has a sack here'.

As discussed in Section 4, the likely source of the nominative possessor encoding is a construction with topicalized possessor where the possessor is expressed as a syntactically detached constituent. In what follows, I will interpret the properties of the nominative possessor in view of its diachronic source and show how its origin may be reflected in its syntactic and semantic properties.

\subsection{The linear position of oblique and nominative possessors in the clause}

Detached topicalized participants are typically located to the left of the clause they are related to (Lambrecht 1994: 182). Accordingly, elicited examples with nominative possessors contained only examples with initially-located nominative possessors, as in (22). In Ovsjannikova 2011, it was shown that nominative possessors cannot follow other core clause constituents, e.g. the subject, whereas for oblique possessors this is perfectly acceptable. The corpus data allow to elaborate on this generalization.

In the majority of examples from the texts, all types of possessors, both oblique and nominative, appear clause-initially, as in (21)-(22). Oblique possessors are also attested non-initially, mostly as a part of a nominal predicate (23).

$\begin{array}{lcc}\text { tfike jefo } \quad \boldsymbol{k a z a} \text {-nij? } & \text { kixu } \\ \text { this yet } & \text { grandmother-OBL.SG.1SG } & \text { idol } \\ \text { i-si-u? } & \quad \eta a-? & \\ \text { NEG-Q-3sG.S.CONT } \quad \text { be(IPFV)-CONN } & \\ \text { 'That was my grandmother's idol'. } & \end{array}$


In line with the generalization based on elicited data, nominative possessors are not encountered in the texts non-initially, except for cases when they are preceded by scene-setting adverbials, as in (24).

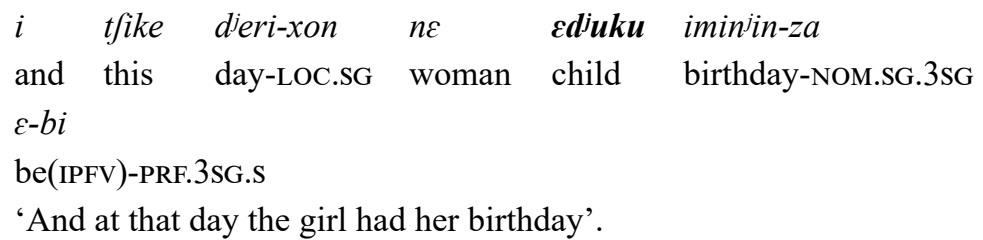

Examples with scene-setting adverbials seem to provide additional evidence that nominative possessors cannot always be viewed as leftdetached constituents outside the clause, as adverbials are clausal and not dislocated constituents, cf. also the arguments against the topicalized status of nominative possessors in Section 4.

Sometimes nominative possessors are placed in the final position, as in (25). As the basic word order in Enets transitive clauses is SOV, these cases should probably be analysed as instances of right dislocation. Still, these final nominative possessors often follow the verb without any intonation break, therefore at least some of these examples do not fully conform to the analysis in terms of right dislocation.

$\begin{array}{llll}n^{i i} i-z a & \text { tวne-P } & n^{i i-m ?} & t / i k e \\ \text { child-NOM.PL.3SG } & \text { be_present(IPFV)-CONN } & \text { NEG-3PL.S.CONT } & \text { this }\end{array}$

buuse-r

old_man-NOM.SG.2sG

'That old man has children, after all'.

Thus, the position of the nominative possessor in the clause indicates its connection to the syntactic mechanism of topicalization but manifests some signs of clause-internal behaviour.

\subsection{The syntactic function of the possessee}

The noun phrase headed by the possessee in clauses both with the oblique and with the nominative possessor constructions can have various syntactic functions. I distinguish the following syntactic functions of the possessees: subjects, e.g. (24)-(25), nominal predicates in 
equative and attributive clauses (23), direct objects (26), oblique objects marked by one of the spatial cases (27), and postpositional or nominal dependents (28).

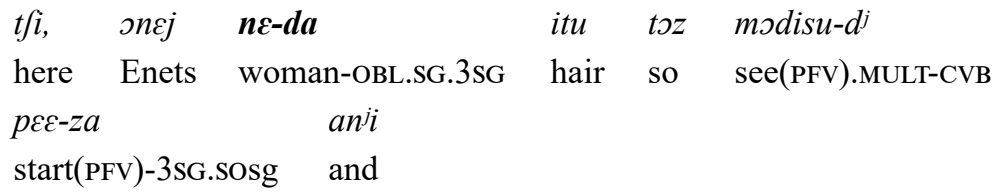

'So, she started searching the hair of the Enets woman'.

(27)

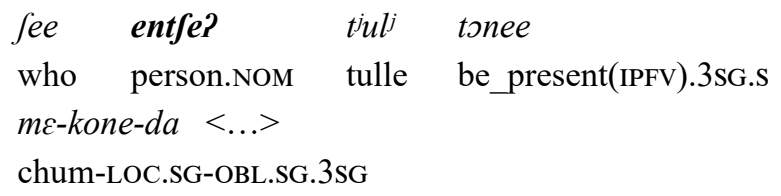

'The whole inside of the Enets girl's tent became water (= got covered with water)'.

The distribution of the examples in terms of the syntactic function of possessees for oblique and nominative possessors is given in Table 3 .

Table 3. The syntactic function of possessees in examples with oblique and nominative human possessors

\begin{tabular}{lccc}
\hline & $\begin{array}{c}\text { Oblique } \\
\text { possessor }\end{array}$ & $\begin{array}{c}\text { Nominative } \\
\text { possessor }\end{array}$ & $\begin{array}{c}\text { Ratio of the } \\
\text { nominative encoding }\end{array}$ \\
\hline Subject & 70 & 71 & 0.5 \\
Direct object & 80 & 2 & $<0.1$ \\
Oblique object & 39 & 3 & $<0.1$ \\
$\begin{array}{l}\text { Postpositional/nominal } \\
\text { dependent }\end{array}$ & 8 & 2 & 0.2 \\
Nominal predicate & 17 & 0 & 0 \\
\hline Total & 214 & 78 & \\
\hline
\end{tabular}


Table 3 shows that while oblique possessors are regularly attested with all syntactic types of possessees, nominative possessors occur mainly in the clauses where the possessee is the subject. When the possessee functions as a direct or oblique object (27), as a postpositional or nominal dependent (28) the nominative encoding of the possessor is possible but much less frequent than the oblique encoding. The uses with the possessee serving as a nominal predicate and the nominative marking of possessor are not found in the sample used for the study. However, outside the sample, there are examples with nominative possessors where the possessee can be regarded as a nominal predicate, cf. (29), so the uses of these type are possible, but very rare.

\begin{tabular}{|c|c|c|}
\hline $\begin{array}{l}\text { nelima-r } \\
\text { nelma-NOM.SG.2SG }\end{array}$ & $\begin{array}{ll}\text { tcxe, } & \text { oncj } \\
\text { there(LOC) } & \text { Enets }\end{array}$ & $\begin{array}{l}m a-d j \\
\text { say(PFV)-CVB }\end{array}$ \\
\hline paпu-za & $\eta a-?$ & $n^{i j-u}$, \\
\hline $\begin{array}{l}\text { period-NOM.SG.3SG } \\
\text { payu-za }\end{array}$ & be(IPFV)-CONN & NEG-3SG.S.CONT \\
\hline
\end{tabular}

'So the nelma [= white salmon], to say it in Enets, it is its time, its time'.

The differences in the distribution of the examples in terms of the syntactic function of the possessee may be attributed to the pragmatic motivation for the nominative vs. the oblique possessor encoding. Although no longer expressed as a syntactically detached constituent, the nominative possessor is a reference point for the situation described by the clause. It is natural, then, for the clause to be about the participant most directly related to the possessor, i.e. the possessee. Thus, the possessee is likely to be topical by virtue of its relation to the possessor and to perform the syntactic function of subject associated with the topic. By contrast, oblique possessors are mainly used in the anchoring function in terms of Koptjevskaja-Tamm (2002: 142), i.e. they help to identify the possessee on the basis of its relation to the possessor. For this reason, oblique possessors are not as selective to the syntactic function of the possessee as nominative possessors. 


\subsection{The semantic class of the possessee}

As shown in the previous subsection, only when the possessee is in the subject position the two types of possessor encoding are equally possible. For this reason, in the following subsections, the semantic class of the possessee and the type of the predicate are analysed using only those examples where the possessee is the subject.

There are two semantic groups of possessees that stand in a special relation to human possessors, viz. body-part nouns and kinship terms. These semantic groups constitute the two major classes of inalienably possessed entities, which are inconceivable without a possessor and have an unchangeable intrinsic connection to their possessor (see Chappell and McGregor 1996, Aikhenvald 2013: 4). In the analysed subsample, nouns denoting body parts and kin functioning as possessees are attested in more than a half of the examples ${ }^{7}$, cf. (30)-(31).

$\begin{array}{llc}\text { buuse } & \text { yo-zi? } & \text { buzimu?ว-? } \\ \text { old_man } & \text { leg-NOM.PL.3DU } & \text { start_moving(PFV)-3PL.S } \\ \text { 'The old man's legs started moving'. }\end{array}$

$\begin{array}{lllll}\text { tfike } & \text { kasa } & \text { etfe-d } & \text { ese } & \text { mana } \\ \text { this } & \text { man } & \text { child-OBL.SG.2SG } & \text { father } & \text { say(PFv).3sG.S }\end{array}$

'That lad's father said'.

Other types of possessees do not naturally fall into any well-defined groups. In particular, they include instruments and other artefacts, like t feziu 'lasso' and kixu 'idol', abstract personal attributes, such as niiu 'name' and mutfizu 'custom', and other nouns. These nouns were treated as a single miscellaneous group. Table 4 shows the distribution of possessor encoding strategies by semantic group of the possessee.

As mentioned in Section 5.1, the main sample used for the study includes only the examples where the possessor is human. No restrictions were imposed on the type of the possessee. 
Table 4. Oblique and nominative possessors and the semantic group of the possessee

\begin{tabular}{lccc}
\hline & $\begin{array}{c}\text { Oblique } \\
\text { possessor }\end{array}$ & $\begin{array}{c}\text { Nominative } \\
\text { possessor }\end{array}$ & $\begin{array}{c}\text { Ratio of } \\
\text { nominative } \\
\text { possessors }\end{array}$ \\
\hline Body-part terms & 2 & 14 & 0.9 \\
Other inanimate possesses & 16 & 26 & 0.6 \\
Kinship terms & 51 & 21 & 0.3 \\
\hline Total & 69 & 61 & \\
\hline
\end{tabular}

The data in Table 4 suggest that the frequency of nominative encoding of the possessor is much higher in clauses with body parts used as possessees than with possessees of other semantic groups, especially kinship terms. As kinship terms refer to human participants and body-part terms, to inanimate participants, this difference might be seen as a reflection of a more general animacy distinction. Still, for body-part terms the frequency of the nominative encoding of the possessor is higher than for the other inanimate possessees in the sample. Examples with nouns denoting animate participants that are not relatives are too few ( 7 in total) to be compared quantitatively with the other groups.

\subsection{The predicate type}

In this section, I consider the type of predicate in the clause with the possessor. Animate and inanimate subjects can be combined with different types of predicates, in particular inanimate subjects are not attested with agentive predicates (at least in my sample). For this reason, predicates in the clauses with animate and inanimate possessees functioning as subjects will be analysed separately.

Predicates in the clauses with animate possessees were classified into agentive, such as 'say' in (31), and non-agentive. Non-agentive predicates include mainly stative verbs (32) and non-verbal predicates (33). 
(32)

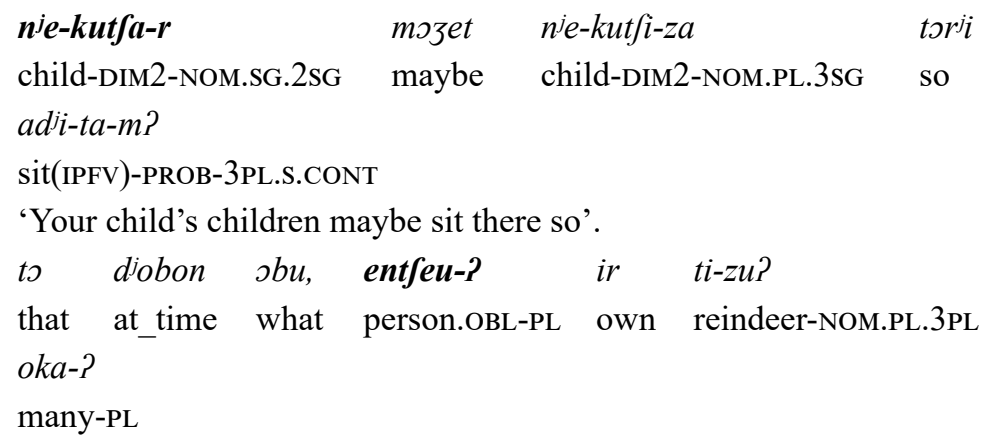

'At that time what, people's own reindeer were numerous'.

Two verbs that semantically pertain to the latter group but are very frequently used in possessive clauses were counted separately, tone 'be present' (27) and its negative counterpart diago 'be absent' (34).

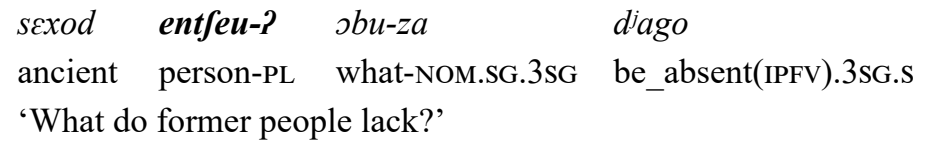

The classification of clauses with inanimate subject possessees was based on morphosyntactic rather than semantic criteria. The predicates were divided into verbs (30) and non-verbal predicates, viz. adjectives and nouns, which are sometimes introduced by an existential verb (35). As in the previous case, examples with the verbs tone 'be present' and d'ago 'be absent' were counted separately.

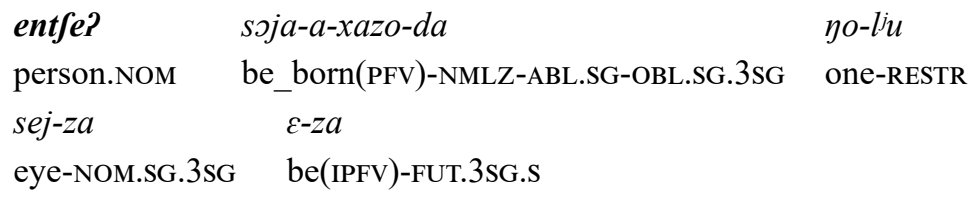

'A person will have one eye from his birth on'.

Table 5 gives the distribution of examples with nominative and oblique possessors by animacy of the possessee and predicate type. 
Table 5. The types of predicates in clauses with nominative and oblique possessors

\begin{tabular}{lccc}
\hline & $\begin{array}{c}\text { Oblique } \\
\text { possessor }\end{array}$ & $\begin{array}{c}\text { Nominative } \\
\text { possessor }\end{array}$ & $\begin{array}{c}\text { Ratio of the } \\
\text { nominative } \\
\text { encoding }\end{array}$ \\
\hline Animate possessees & 30 & & \\
Agentive predicates & 14 & 8 & 0.1 \\
Non-agentive predicates & 6 & 17 & 0.4 \\
'be present' / 'be absent' & 50 & 29 & 0.7 \\
\hline Total & & & \\
\hline Inanimate possessees & 6 & 7 & 0.5 \\
Verbal predicates & 8 & 19 & 0.7 \\
Non-verbal predicates & 2 & 16 & 0.9 \\
'be present' / 'be absent' & 16 & 42 & \\
\hline Total & & & \\
\hline
\end{tabular}

Table 5 shows that in the clauses with animate possessees nominative possessors tend to occur more frequently with non-agentive than with agentive predicates. When the subject is agentive (36), the situation is not likely to be described relative to another human participant, i.e. as happening in his/her domain of interest.

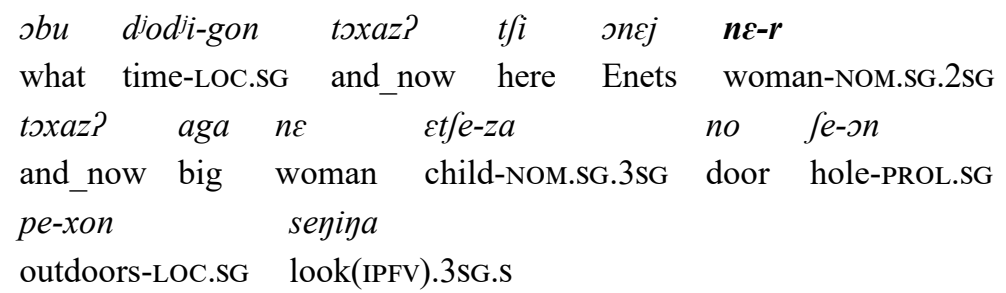

'At some time then the Enets woman's elder daughter looks outside through the door hole'.

The motivation for the nominative encoding of the possessor in the clauses with agentive predicates is to be sought for not in the semantics of the clause containing the possessor but in the broader context. Indeed, the nominative possessors in the clauses with agentive predicates all seem to be the main protagonists of the preceding discourse. Example (36) is particularly telling since the central participant of the 
previous clauses of the narrative, the Enets woman, has just been killed by the witch. Thus, the nominative encoding of this possessor can only be attributed to her discourse prominence and not to her semantic properties in the clause (36).

Non-agentive predicates are more likely to describe events that are viewed from the possessor's perspective, as the subject is usually nonvolitional, as in (32) above.

Among the examples with inanimate possessees and verbal predicates, the oblique encoding of possessor is presumably associated with the semantic alienability of the possessee, i.e. the possibility of its existence independently of the possessor. For instance, in (37) the possessee 'overcoat' is a participant of an event where its possessor is absent. By contrast, in examples with verbal predicates where the possessees are expressed by body-part terms, which are inconceivable without the possessor, only the nominative encoding is attested, cf. (38) and (30) above.

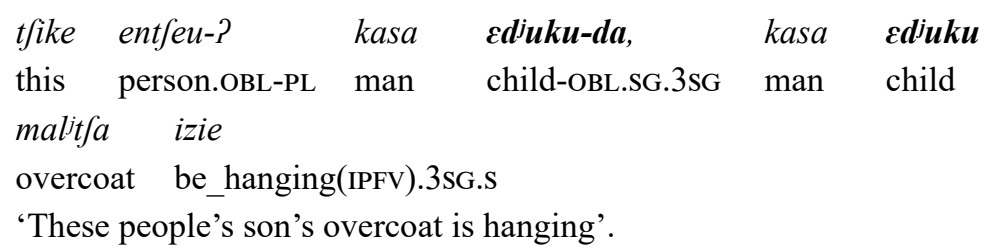

$\begin{array}{lll}\text { kasa-j?, } & \text { man-? } & n^{j} \text { e-zur, } \\ \text { man-NOM.SG.1SG } & \text { say(PFV)-CONN } & \text { NEG-1SG.S.CONT } \\ \text { cba-za } & \text { pगferi } & \\ \text { head-NOM.SG.3SG } & \text { whirl(IPFV).3sG.s }\end{array}$

'My mate's, I say, head goes round (= My mate is feeling dizzy)'.

These differences between alienable and inalienable possessees may be interpreted in terms of the degree to which the possessor is affected by the event. The degree of affectedness is likely to be the highest when the possessee is the possessor's body part. Thus, in the clauses with inanimate possessees and verbal predicates the choice of the possessor encoding is determined primarily by the semantics of the situation, i.e. by the relation between the possessor and the possessee and the affectedness of the possessor. This semantic motivation of the nominative possessor encoding is distinguished here from the discourse motivation, suggested above for the contexts with agentive predicates, on the one 
hand, and constructional motivation, associated with a specific type of construction, which is discussed below, on the other hand.

In clauses with inanimate possessees, the nominative possessor encoding is more frequent when the predicate is non-verbal, i.e. adjectival or nominal, rather than verbal. The possessor encoding in these examples with non-verbal predicates is strongly associated with constructions employed to express a specific situation type.

In particular, the nominative encoding is consistently used for the possessor in the constructions describing a person's name. In these examples, the possessee is expressed by the noun niiu 'name' functioning as the subject and the name of the possessor is the predicate (39).

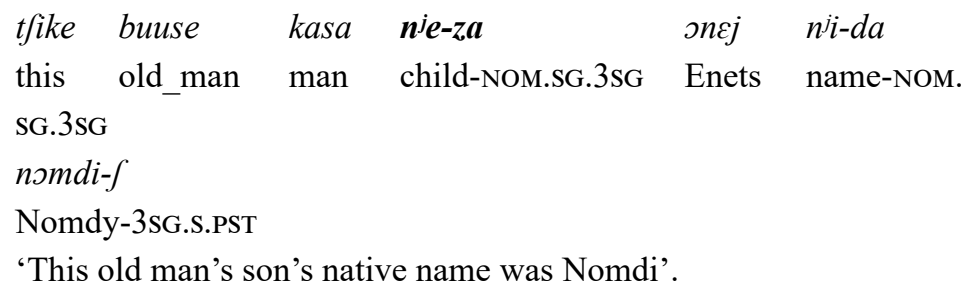

Nominative possessor encoding is also the default option for another type of clauses that predicate the possessive relation between the possessor and the possessee, i.e. for the clauses with nominal predicates (with or without existential verb), as in (35) above. These clauses constitute one of the marginal types of Enets predicative possessive constructions to be discussed in Section 6.2 below.

Finally, in clauses with both animate and inanimate possessees, the highest proportion of nominative possessor encoding is observed among clauses with the verbs tone 'be present' and diago 'be absent' (40)-(41).

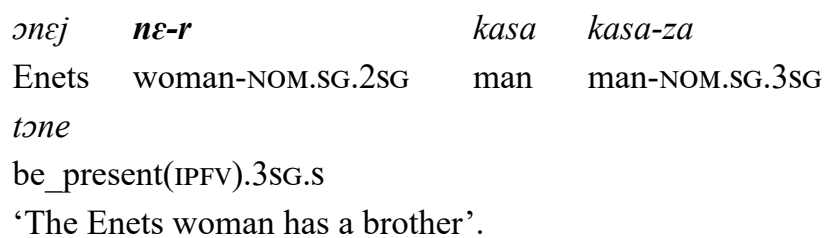

$\begin{array}{lll}\text { kasa-xuи-n } \boldsymbol{i} \boldsymbol{i} ? & \text { benzin-zi? } & \text { diago- } \int \\ \text { man-DU-PL.1SG } & \text { petrol-NOM.SG.3DU } & \text { be_absent(IPFV)-3SG.S.PST } \\ \text { 'But my mates had no petrol'. } & \end{array}$


Clauses with these two predicates are regularly used to denote possession and can be viewed as the main type of predicative possessive constructions in Enets. Elicited data suggested that in the clauses with these predicates, the oblique possessor marking is impossible (Ovsjannikova 2011). In the sample under study, however, there are 8 cases of oblique possessor encoding in the clauses with the verbs tone 'be present' and diago 'be absent' (as opposed to 33 cases of nominative encoding, cf. Table 5). These eight clauses fall into two groups. The first group includes five examples in which the possessive or locative relation is predicated of another participant rather than the oblique possessor in question. For instance, example (42) asserts the presence of the possessee at a certain location (Yamal).

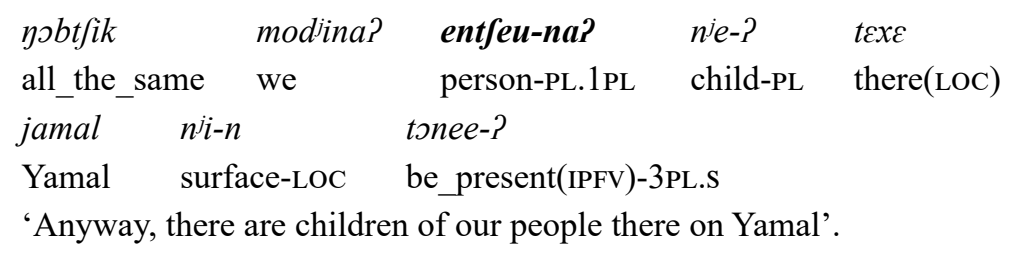

Examples of this type do not refute the restrictions on the use of oblique possessors in predicative possessive constructions suggested by the elicited data, since these oblique possessors are not the participants the possessive relation is predicated of.

In the three examples comprising the second group, however, the possessive relation is indeed predicated of the oblique possessor, as in (43).

\begin{tabular}{|c|c|}
\hline tjike disi-ni? & $\varepsilon s e-z a$ \\
\hline this grandfather-OBL.SG.1sG & father-NOM.sG.3sG \\
\hline tonie-bi & $a n^{i} i$ \\
\hline be_present(IPFV)-PRF.3sG.S & and \\
\hline
\end{tabular}

It is remarkable that in all these examples the possessees are human and they are all marked with a possessive marker. As discussed above, possessive marking of the possessee is characteristic of the nominative possessor encoding and marginal for clauses with oblique possessors. These examples can be viewed as a mixed type in terms of morphosyntactic properties and as a case of competing tendencies in terms of 
semantic properties. On the one hand, the possessors of human possessees tend to be oblique; on the other hand, the verbs tone 'be present' and d'ago 'be absent' are strongly associated with the possessor that serves as a reference point for the whole clause, i.e. with the nominative possessor ${ }^{8}$.

The analysis undertaken above suggests that the motivation for the choice of the possessor encoding strategy may lie in various domains. There are examples where the nominative encoding of possessor can be accounted for only by the discourse properties of the possessor participant. This factor seems to be relevant mainly for the clauses with animate possessees functioning as subjects of agentive verbs. In the majority of cases, however, the nominative possessor encoding is likely to be primarily determined clause-internally, either by the semantics of a situation or by the type of construction. Semantically, nominative possessors are associated with inanimate rather than animate possessees and, among inanimate possessees, with those that correspond to body parts. The constructions typically triggering the nominative encoding of possessors describe situations of which the possessor constitutes an indispensable part, viz. the constructions asserting the possessive relation, communicating a person's name and age.

The next section consists of two parts. The first part presents an overview of the possessor encoding strategies in other Samoyedic languages, as reported in the existing descriptions, and compares them to the inventory of possessive encoding strategies attested in Enets. The second part focuses on the conditions of use of the Enets nominative possessor and discusses them against the background of the functionally similar phenomena in other languages.

Another possible motivation for possessive marking of human possessees in these contexts suggested to me by Gerson Klumpp is that being mostly kinship terms these possessees could be habitually used with possessive marking, even when used with oblique possessors. 


\section{Discussion}

\subsection{Possessor encoding in Samoyedic languages}

There are numerous works on possessive constructions in Samoyedic. In contrast to the present study, these works usually treat predicative and attributive possessive constructions separately, either focusing only on one of these domains or examining them in different sections. The majority of the existing accounts seem to agree upon the following points.

In most of Samoyedic languages, predicative possession is expressed by a construction with an existential predicate and the possessee expressed as the subject (cf. Honti 2008: 165, Wagner-Nagy 2011: 222 257). In Nganasan, this strategy is employed along with the transitive construction with the dedicated verb honsi 'have' (Wagner-Nagy 2011: $250,2014)$. Selkup stands apart from the other languages in that the possessor in the predicative possessive construction is predominantly encoded as a locational, i.e. by the locative case or postposition, depending on the dialect (see Wagner-Nagy 2011: 223-228, Budzisch 2015, Kim-Malony and Kovylin 2016). In some other Samoyedic languages, the locative encoding of possessor is also possible, but it is likely to be associated with temporary rather than permanent possession (see Wagner-Nagy 2011: 234, 256 on Nenets and Nganasan). In Enets, the locative marking of possessor is very rare. Most of such examples may be indeed interpreted as describing the object as being at the possessor's disposal or his dwelling rather than focusing on the permanent relation of ownership, cf. (44).

$\begin{array}{lll}\text { entfe-gin } & a n^{i} i \quad d^{i} u d a-r & d^{j a g o-j} \\ \text { person-LOC.PL } & \text { and horse-NOM.SG.2SG } & \text { be_absent(IPFV)-PTCP.ANT } \\ \text { yaa-? } & n^{i} i u ? & \\ \text { be(IPFV)-CONN } & \text { NEG-3SG.S.CONT } & \\ \text { 'People had no horses'. }\end{array}$

In the domain of attributive possession', genitive is usually the only regularly attested strategy (see Tereščenko 1973: 213ff. on Samoyedic

As discussed in Section 2, attributive possessive constructions are understood as those where the possessive relation is presupposed rather than asserted, without any implications for the syntactic status of the possessor. 
languages in general, Nikolaeva 2014: $142-150$ on Tundra Nenets, Wagner-Nagy 2014: 76-77, 2018: 317 on Nganasan, Budzisch 2015 on South Selkup). As indicated in Section 2, the oblique form of possessor in Enets is also often analysed as the genitive case form, and this is the only way of possessor encoding recognized in the grammatical descriptions (Sorokina 2010, Siegl 2013). The possibility of the nominative encoding of attributive possessors is not reported in the abovementioned studies, except for a brief discussion of several Nganasan examples by Tereščenko (1973: 42) ${ }^{10}$.

Evidence for the possibility of nominative encoding of possessors in predicative possessive constructions of other Samoyedic languages beyond Enets is somewhat inconsistent. Both for Nenets and for Selkup, there are studies that mention the nominative possessor construction among the ways to express predicative possession (see Wagner-Nagy 2011: 228-233 on Nenets, and ibid.: 223-227, Budzisch 2015 on Selkup; cf. also Honti 2008: 165-166). At the same time, the descriptions of Tundra Nenets by Nikolaeva (2005, 2014: 251-252) and of Selkup predicative possessive constructions by Kim-Maloni and Kovylin (2016) do not mention this possibility for the languages in question. In Nganasan, according to Wagner-Nagy (2011: 250-257, 2018: 360), the nominative possessor construction exists along with the transitive construction.

Thus, without corpus studies, it is difficult to determine exactly the extent to which the constructions with nominative possessors are spread in the Samoyedic languages. Still, it is noteworthy that the nominative encoding of possessors is mostly mentioned for predicative rather than for attributive possessive constructions.

10 This applies only to referential nominative possessors that tend to be topical and do not belong to the noun phrase headed by the possessee, as discussed in Section 4 for Enets. In Samoyedic languages, there is also a type of noun modifiers in the nominative case that are non-referential and describe type or material of the head noun (see Tereščenko 1973: 203, 205, for Nenets Tereščenko 1962: 83, Nikolaeva 2014: 165-167, for Nganasan Wagner-Nagy 2018: 316). In particular, they typically include combinations like kasa $n^{j} e<$ man child > 'son' or te ssa 'reindeer meat'. As Enets nouns of the default inflectional class do not distinguish between the nominative and the genitive (oblique) case forms, it is difficult to judge on the spread of the uses with non-referential nominative nominal modifiers; for the Enets nouns that have oblique stems, such uses seem to be rare. 
In Section 4.2, the distribution of the nominative and the oblique encoding of possessors in Enets will be reviewed with the focus on the semantic and pragmatic properties of constructions they are associated with. In particular, it will be claimed that Enets possessive constructions are better analyzed if predicative and attributive possession are viewed as a single domain, as in this paper.

\subsection{Semantic types of constructions and possessor encoding}

The major way to express predicative possession in Enets is the construction with the verb tone 'be present', usually replaced by the verb diago 'be absent' when possession in negated, cf. (40)-(41). The possessee is the syntactic subject, and the possessor is predominantly encoded by the nominative case. As discussed above, the nominative encoding of possessors is likely to be diachronically motivated by the possessor topicalization mechanism. Thus, in terms of the typological classification proposed by Stassen (2009: 57-59, 2013), the Enets predicative possessive construction should be qualified as the Topic Possessive. This makes Enets (probably along with Nganasan, see 4.1) one of the rare instances of this type among the languages of Northern Eurasia, at least to the extent they are represented in Stassen 2009 and 2013. The Topic Possessive is attested as a secondary strategy in Japanese, Korean and Manchu, its highest concentration as the major strategy is found among the languages of Southeast Asia reaching as far as New Guinea (see ibid.) ${ }^{11}$.

At present, the topic-like encoding of the possessor in Enets predicative possessive construction is likely to be constructionally rather than pragmatically motivated, as suggested by the syntactic properties of nominative possessors (discussed in Section 3) as well as the low acceptability of the alternative oblique encoding in this construction (see 4.5 and Ovsjannikova 2018).

11 A recent paper by Chapell and Creissels (2019) argues against considering the Topic Possessive as one of the basic types of predicative possessive constructions. They analyse some of the Southeast Asian languages classified by Stassen $(2009,2013)$ as having Topic Possessive as the major strategy and show that in some of these languages, the Topic Possessive should be regarded as a secondary strategy and in others, the predicative possessive construction should be reclassified as either the Locational or the HavePossessive. 
Along with this basic type of predicative possessive construction, possessive relations can be expressed by a construction consisting only of the possessor and possessee noun phrases, without the verb tone 'be present', as in (45). The possessor in this constructions is always in the nominative case.
пехи?, $\varepsilon \varepsilon-b i$ ?
пехи? $n \varepsilon$
$n^{i} e-z a$
three
mother-NOM.SG.1SG
three woman
child-NOM.SG.3sG
'Three, my mother has three daughters'.

In these clauses, as in the majority of clauses with non-verbal predicates, no existential verb is used in present and past tense contexts, cf. (45) and (39) above. In other contexts, there is the existential verb $\varepsilon / \eta a$ 'be', which takes temporal or modal markers, see (35) above.

Grammatically, this construction is especially favoured in contexts where the possessee is accompanied by a modifier that does not itself function as a non-verbal predicate, most commonly by a numeral ${ }^{12}$. Accordingly, this type of possessive construction is regularly used if the possessee is likely to be specified in terms of its number, e.g. children, as in (45) (cf. Wagner-Nagy 2011: 237 on the frequent use of this construction to express the number of children). Another type of possessive relation this construction often encodes is that of a person and their age, i. e. the number of years (46). Thus, in Enets, the age of a possessor, which is one of cognitively salient marginal types of possessive relations (Stolz and Stolz 2009), falls outside the domain of the basic predicative possessive construction.

$$
\begin{array}{lllll}
\text { texe } & n \varepsilon & \varepsilon t f e-z a, & n \varepsilon & \varepsilon t f e-z a \\
\text { there(LOC) woman } & \text { child-NOM.SG.3SG } & \text { woman } & \text { child-NOM.SG.3sG } \\
\text { fize } \quad p \text {-kutfa-za- } \int & & & \\
\text { two year-DIM2-NOM.SG.3SG-PST } & &
\end{array}
$$

'So her daughter.... her daughter was two years old'.

12 It is noteworthy that in terms of the choice of the verb this construction patterns with clauses with non-verbal predicates that semantically serve to describe location or attributes of a definite subject, rather than with clauses with the verb tone 'be present' that appear in existential clauses with indefinite subjects (cf. Wagner-Nagy 2016). Thus, it is possible that these clauses communicate primarily the number of possessed items rather than the fact of possession as such. 
Along with these possessive constructions, a type of context strongly associated with the nominative encoding of the possessor is the construction describing a person's name (47), see also (39) above. Grammatically, these constructions are non-verbal clauses with the subject expressed by the noun niiu 'name' and the proper name in the function of the predicate, with or without the verb $\varepsilon / \eta a$ 'be' depending on the tense and modality of the clause. The possessor of the name is encoded by nominative.

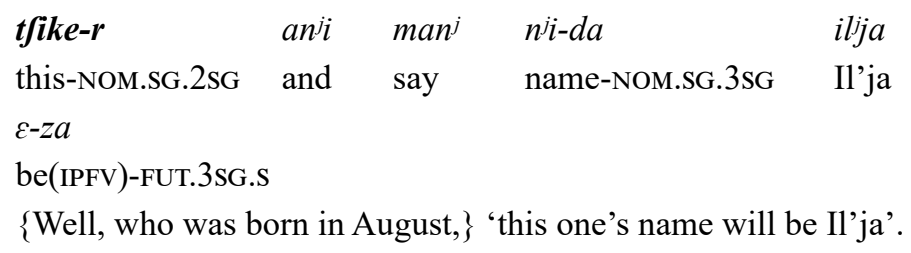

The common property of the constructions reviewed in this section so far is that they all communicate something about the possessor, not about the possessee. The most evident case of this bipartite communicative structure is the basic predicative possessive construction, which by definition asserts the possessive relation between a possessor, who is usually human and definite, and a possessee which is typically indefinite. This analysis can also be applied to the minor type of the predicative possessive construction, which is associated with possessees modified by numerals, especially when used to describe the age of a possessor. The construction describing a person's name, technically speaking, is a case of attributive possession. Still, the most natural function of this construction, as well as of the construction expressing age, is to characterize the possessor in terms of these properties.

Apart from these constructions, the nominative encoding of possessor is favoured when the possessee is a body part, as in (48)-(49). In (48), the possessor is cross-referenced on the noun aja 'body', which is syntactically a modifier of the noun $t o$ ? 'hair'. Despite the syntactically low position of the "official" possessee, it is obvious that the clause describes the effect of the event on the witch rather than the change of state of her hair as such (as the result of the event, the witch gets burned down and her ashes turn into mosquitoes). 
(48)

$\begin{array}{lllll}\text { olasne-r } & t \text { tike } & \text { aja-da } & \text { to? } & \text { toz } \\ \text { witch-NOM.SG.2SG } & \text { this } & \text { body-OBL.SG.3SG } & \text { hair } & \text { so } \\ \text { lojru-j-da } & & & & \\ \text { flame_up(PFv)-PTCP.ANT-OBL.SG.3SG } & & \end{array}$

'So the hair of the witch's body flamed up'.

$\begin{array}{llll}\text { tfike-r } & \text { uze } & \text { iblicjgu-on, } & \varepsilon t> \\ \text { this-NOM.SG.2SG } & \text { already } & \text { small-PROL.SG } & \text { so } \\ \text { tabu-da } & \text { kauja } & \\ \text { hair-NOM.SG.3SG } & \text { fall(IPFv).3sG.s } & \end{array}$

'Its hair already gradually, well, falls' .

It should be noted that body parts rarely function as possessees in the predicative possessive constructions. Indeed, there is usually no need to assert the possessive relation with body parts, which belong to a given animate possessor by default. At the same time, the predicative possessive constructions with body part terms functioning as possessees are not completely absent in the corpus, especially in the clauses with the negative verb diago 'be absent', cf. also (35), which describes the possessor having one eye. Still, the majority of corpus examples with possessees expressed by body-part terms are the instances of attributive possessive constructions, cf. (48)-(49).

On the one hand, sentences like (48)-(49) do not have such a pronounced bipartite communicative structure where the possessor is opposed to the rest of the clause, as observed in the constructions discussed above. In particular, both the possessor and the body part can be viewed as a topical participant whose state is asserted. On the other hand, as mentioned in Section 5.4, body parts normally presuppose the presence of the possessor in the situation. Moreover, the (change of) state of a body part bears on the state of its possessor, and the possessor is often affected by virtue of his/her relation to the body part. In this respect, nominative possessors in these contexts can be viewed as functionally similar to external possessors in other languages. In the constructions with external possessor the possessor is usually affected and the possessee is often the body part (cf. König and Haspelmath 1997). In some languages, internal possessors in this type of contexts are found to manifest specific syntactic behaviour expected for prominent clauselevel arguments of the verb (agreement with the predicate and participa- 
tion in interclausal co-reference relations), as discussed (Nikolaeva et al. 2019) under the notion of prominent internal possessors. The major difference between these two types of constructions and Enets nominative possessors is that the former are more likely to be found when the possessee is expressed as an object than when it is the subject (cf. König and Haspelmath 1997 on external possessors, Nikolaeva et al. 2019: 19-22 on prominent internal possessors). As shown above, in Enets, the nominative encoding of possessor is much more frequent when the possessee is the subject rather than any other syntactic relation. These clauses with subjects expressed by body-part terms are usually headed by intransitive perfective and imperfective verbs (48)-(49) and sometimes by adjectives (1)-(2).

Some of the clauses with body parts in the function of the subject are idioms that conventionally describe a specific state or property of the possessor rather than that of the body part. For instance, an event of being suddenly frightened is often denoted by a lexicalized combination of the noun $s \varepsilon j u$ 'heart' serving as the syntactic subject and the perfective verb kanje 'leave', as in (50). Similarly, example (51) primarily describes the mental event of thinking on the part of the possessor, not the state of the body part as such. The possessor in these constructions is consistently encoded in the nominative case.

$\begin{array}{lccc}\text { su, tfike } & \text { kasa-xuu-za, } & \text { fize } & \text { kasa-xuu-za } \\ \text { EXC this } & \text { man-DU-NOM.PL.3SG two } & \text { man-DU-NOM.PL.3SG } \\ s c j i-z i ? & k a n^{j} e-? & & \\ \text { heart-NOM.PL.3DU leave(PFV)-3PL.s } & & \end{array}$

'Oh, the mates, the two mates got afraid' (lit. 'the mates' hearts left').

\begin{tabular}{|c|c|c|}
\hline oncj & $n \varepsilon-r$ & $b i i-r u-z a$ \\
\hline $\begin{array}{l}\text { Enets } \\
\text { kojdena }\end{array}$ & woman-NOM.SG.2sG & mind-RESTR-NOM.SG. $3 \mathrm{sG}$ \\
\hline
\end{tabular}

'The Enets woman only thinks' (lit. 'Only the mind of the Enets woman moves').

Heine notes that at the early stages of development, attributive possessive constructions following the Topic Schema are typically used when "the possessor and the possessee have the same general referent" 
(Heine 1997: 159), which is most clearly true for body parts and their possessors. The possessive constructions of this type, traditionally called "double subject constructions", are wide-spread in the languages of East Asia (ibid.: 160; see also Chappell 1996, Shibatani 2001: 329). According to Heine (1997: 160), double subject constructions are usually found in clauses with intransitive or stative predicates that describe the possessor's physiological or psychological state through the state of the relevant body part. Enets clauses with nominative possessors and body-part terms as possessees in the subject function are similar to the double subject constructions in terms of the grammatical marking of the possessor and the possessee, their semantic relation and the clause type. The only crucial difference is that the nominative possessor in Enets does not exhibit any syntactic properties of the subject, at least it cannot trigger agreement, as the subjects in Enets do.

If we set aside the issue of case marking, the distinction between two possessive constructions similar to the one observed in Enets is also found in Tundra Nenets (Nikolaeva 2014: 221-223, cf. also an earlier account in Nikolaeva 2005). According to Nikolaeva, the nominal, or lexical, possessor in Nenets can only be expressed by the genitive case. These genitive possessors can be either internal to the possessee noun phrase or external. Nenets external genitive possessors exhibit remarkable similarity to Enets nominative possessors in terms of syntactic properties, functional motivation and distribution. Grammatically, they are obligatorily cross-referenced by a possessive suffix on the possessee and can be separated from it by clause-level adverbs. The possessors of this type are also typically attested when the possessee is the subject. Functionally, Nenets external genitive possessors are associated with the topicality of possessor; at the same time, these possessors "can be non-topical, especially in predicative possessive constructions $\langle\ldots>$ or with other intransitive verbs" (Nikolaeva 2014: 223). As Enets nominative possessors, external possessors in Nenets are obligatorily used in predicative possessive constructions, where they can be non-referential and can be expressed by an interrogative pronoun (ibid.: 250-251).

Typologically, the strategy of encoding predicative possession employed in Nenets corresponds to the Genitive Schema in terms of Heine (1997: 58-59) and to one of the subtypes of Adnominal Possessives in terms of Stassen (2009). According to the definition, in this type of predicative possessive constructions, the possessor is marked 
in the same way as in the attributive possessive constructions (Heine 1997: 58, Stassen 2009: 107). As discussed by Stassen (2009: 113-122), despite the identity of the morphological marking in the attributive and the predicative possessive constructions, in some languages of this type, the possessor and the possessee in the predicative possessive construction do not form a single syntactic constituent, while in the attributive possessive constructions they do. Importantly, Stassen explains these syntactic differences in terms of possessor topicality: the possessor is topical in predicative possessive constructions and does not have this status in attributive possessive constructions, see (ibid.: 118-122).

Although the predicative possessive construction in these languages may indeed be the most salient context with a topical possessor, the discussion of the Nenets possessive constructions by Nikolaeva (2005, 2014: 221-223) suggests that, at least in some languages, the borderline between the external and the internal genitive possessors does not coincide exactly with the distinction between attributive and predicative possession. Another case in point is the construction with the "floating genitive" in Northern Akhvakh (Andic $<$ Northeast Caucasian) discussed in Creissels 2013. Syntactically, the floating genitives, unlike other genitive forms denoting possessors, do not form a part of the noun phrase headed by the possessee. Functionally, "floating genitives express that the situation to which the clause refers is the personal sphere of their referent" (ibid.: 346), in particular the floating genitive is used to encode the possessor in the predicative possessive construction. Based on this functional motivation, Creissels proposes to analyse the floating genitives as a particular type of external possessor constructions. The syntactic and functional similarity to external possessor constructions is also observed for some uses of the genitive case form in Bashkir (Turkic < Altaic) (Ovsjannikova and Say 2014). Bashkir lacks oblique external possessors and uses the genitive case to encode referential possessors both in attributive and the predicative possessive constructions. Still, the syntactic behaviour of the genitive case forms with respect to constituency tests differ depending on the degree of affectedness and indispensability of the possessor in the situation described by the clause. The possessor in the predicative possessive construction shows the highest degree of syntactic independence from the possessee. However, the various genitive possessors in the domain of attributive possession can also be ordered on the scale from more 
syntactically independent and more affected in the situation (as e.g. in clauses like 'Bulat's head aches' ${ }^{13}$ ) to more integrated into the possessee noun phrase and less affected (as in clauses like 'Bulat's brother lost the keys'). Thus, although syntactically and functionally some of the genitive possessors in Bashkir are similar to external possessors, a more plausible analysis is that the various genitive possessors form a continuum from more to less pragmatically salient and, accordingly, from more to less syntactically independent. The typologically relevant distinction between predicative and attributive uses here again reflects just one of the possible boundaries along this continuum.

This subsection started out from examining the semantic types of constructions where the nominative encoding of possessors is predominant in Enets. The constructions that belong to this range fall into two types depending on the proposed motivation for the nominative encoding of the possessor. The first type includes constructions that describe possessive relations understood in a broad sense, including the constructions used to communicate a person's age and name. In the constructions of this type the possessor is an indispensable part of the situation semantics and necessarily serves as the participant the clause is predicated of. The constructions of the second type describe a state or a change of state of body parts. As the possessor is likely to be affected by virtue of the possessive relation to a body part, the possible motivation for the nominative encoding in the clauses of this type is the affectedness of the possessor. Both semantic indispensability and affectedness are sufficient grounds for encoding possessor as the reference point relative to which the situation is to be interpreted. In all these constructions the possessors can also be expected to be topical in the natural discourse environment. Still, as argued above, the nominative encoding of possessor is possible out of context (e.g. elicited without any preceding context) and in many

13 It is noteworthy that in Bashkir clauses describing the situations of hurting, or aching, the possessor was found to be more syntactically independent than in the clauses with the meaning, e.g., 'X's head is large' (see Ovsjannikova and Say 2014). Likewise, in Enets, for the verb die 'ache', the nominative marking of the possessor is obligatory (Ovsjannikova 2018), in contrast to the attributive clauses with adjectival predicates, which allow for the oblique possessor encoding. Shibatani (2001: 340) reports a similar restriction for the Japanese predicate 'hurt', that can only be used in the double subject construction, and not with the genitive possessor. These facts indicate that the affectedness of the possessor can be reflected in the grammatical properties of the construction even when the type of possessive relations is held constant. 
of the contexts discussed above it turned out to be the only acceptable option. It may be hypothesized that diachronically these were the contexts where the topicalization of possessor was especially wide-spread and, consequently, became associated with these constructions as their syntactic property.

From the typological perspective, the nominative possessor encoding in Enets is largely paralleled by functionally similar phenomena in other languages. In particular, in a number of languages of Northern Eurasia, including Nenets, there is a distinction between different types of genitive possessors, where the more syntactically independent types are associated with a range of contexts very close to those observed for the Enets nominative possessors. This range of contexts usually includes the predicative possessive construction but is not confined to it. It is also important that for most of the languages discussed above, including Enets, the distribution of the different types of possessors is a matter of frequency rather than of a categorical choice. While the Enets constructions overviewed in this section manifest the most consistent nominative encoding of possessors, the contexts outside this domain can also accommodate nominative possessors to varying degrees.

\section{Conclusion}

The two major types of encoding nominal possessors in Enets are the nominative encoding and the oblique (genitive) encoding. In terms of syntactic properties, the oblique possessor behaves as a part of the noun phrase headed by the possessee. The properties of the nominative possessors suggest that this type of encoding is based on the mechanism of topicalization but presently is on its way to becoming syntactically rather than pragmatically motivated. On the one hand, the nominative possessor is syntactically outside the possessee noun phrase and cannot follow other core clausal arguments, which is typical of topics. On the other hand, it can be preceded by scene-setting adverbials and is allowed inside dependent clauses, which is unexpected for topics. The mixed grammatical behaviour of the nominative possessor is paralleled by its functional distribution. Along with examples where the nominative encoding of the possessor is likely to be triggered by its prominent role in preceding discourse there are contexts where the nominative 
encoding is triggered by the type of the construction or is associated with the semantic affectedness of the possessor. These contexts include predicative possessive constructions, as well as clauses describing the state of the possessor's body parts. The distribution of the two possessor encoding strategies in Enets suggests that for a language where the predicative possessive construction is based on an existential predication, considering predicative and attributive possession together can be more fruitful than keeping them apart.

Possible typological parallels to the Enets nominative possessor are external possessor constructions, double subject constructions found in many languages of East Asia, and especially the syntactically emancipated types of genitive possessors reported in a number of languages of Northern Eurasia. These morphologically variegated phenomena show a significant functional similarity in that they set off semantically salient possessors from those that only serve to determine the identity of the possessee.

\section{Acknowledgements}

This study was supported by the grant 17-34-01068-OGN of the Russian Foundation for Basic Research. I thank Olesya Khanina, Sergey Say, Andrey Shluinsky and the anonymous reviewer for their comments and suggestions. Naturally, all the errors and misinterpretations are my responsibility. I am also deeply grateful to all the speakers of Enets I had the privilege to work with.

\section{Address}

Maria Ovsjannikova

Institute for Linguistic Studies, RAS

Tuchkov pereulok, 9

199004 St. Petersburg

Russia

E-mail: masha.ovsjannikova@gmail.com 


\begin{abstract}
Abbreviations
1, 2, 3 - 1st, 2nd, 3rd person, ABL - ablative case, ADJ - adjectivizer, ANT - anterior, COND - conditional, CONN - connegative, CONT contrastive agreement markers, CVB - converb, DIM - diminutive, DU dual, EVEN - concessive nominal marker, EXC - exclamative particle, FUT - future, INC - inchoative, LOC - locative case, MULT - frequentative, NEG - negative verb, NMLZ - nominalization, NOM - nominative case, OBL - oblique case, PL - plural, PLC - placeholder, PRF - perfect, PROB - probabilitive, PROL - prolative case, PST - past, PTCP - participle, Q - interrogative marker, RESTR - suffix meaning 'only', s - subject agreement markers, SG - singular, SIM - simultaneous, SO.SG - subjectobject agreement markers for singular object, TRANSL - translative
\end{abstract}

\title{
References
}

Aikhenvald, Alexandra Y. (2013) "Possession and ownership: a cross-linguistic perspective". In Alexandra Y. Aikhenvald and Robert M. W. Dixon, eds. Possession and ownership: a cross-linguistic typology, 1-64. Oxford: Oxford University Press. https://doi.org/10.1093/acprof:oso/9780199660223.003.0001

Budzisch, Josefina (2015) "Possessive constructions in Southern Selkup dialects". Tomsk Journal LING \& ANTHRO 4, 10, 45-50.

Bybee, Joan (2001) "Main clauses are innovative, subordinate clauses are conservative: consequences for the nature of constructions". In Joan Bybee and Michael Noonan, eds. Complex sentences in grammar and discourse: essays in honor of Sandra A. Thompson, 1-17. Amsterdam: John Benjamins.

Chappell, Hilary (1996) "Inalienability and the personal domain in Mandarin Chinese discourse". In Hilary Chappell and William McGregor, eds. The grammar of inalienability: a typological perspective on body part terms and the part-whole relation, 465-527. Berlin and New York: De Gruyter.

Chappell, Hilary and Denis Creissels (2019) "Topicality and the typology of predicative possession”. Linguistic Typology 23, 3, 467-532.

https://doi.org/10.1515/lingty-2019-0016

Chappell, Hilary and William McGregor (1996) "Prolegomena to a theory of inalienability". In Hilary Chappell and William McGregor, eds. The grammar of inalienability: a typological perspective on body part terms and the part-whole relation, 3-30. Berlin and New York: De Gruyter. https://doi.org/10.1515/9783110822137.3

Creissels, Denis (2013) "Floating genitives and possessive framing in Northern Akhvakh”. In Anne Carlier, Jean-Cristophe Verstraete, eds. The Genitive, 333-354. Amsterdam and Philadelphia: John Benjamins. 
Heine, Bernd (1997) Possession: Cognitive sources, forces, and grammaticalization. Cambridge: Cambridge University Press.

Herslund, Michael and Irène Baron (2001) "Introduction: dimensions of possession". In Irène Baron, Michael Herslund, and Finn Sørensen, eds. Dimensions of possession, 1-25. Amsterdam and Philadelphia: John Benjamins.

Honti, Làszlò (2008) “'Habere' po-uralski”. Linguistica Uralica 44, 3, 161-177. https://doi.org/10.3176/lu.2008.3.01

Kim-Maloni, Aleksandra Arkadievna and Sergej Vasil'evič Kovylin (2016) "Strategii formirovanija predikativnoj posessivnosti v sel'kupskix dialektax". Tomsk Journal $L I N G \&$ ANTHRO 4, 14, 9-21.

König, Ekkehard and Martin Haspelmath (1997) "Les constructions à possesseur externe dans les langues d'Europe". In Jack Feuillet, ed. Actance et valence dans les langues de l'Europe, 525-606. Berlin: Mouton de Gruyter.

Koptjevskaja-Tamm, Maria (2002) "Adnominal possession in the European languages: form and function". Sprachtypologie und Universalienforschung 55, 2, 141-172. https://doi.org/10.1524/stuf.2002.55.2.141

Lambrecht, Knud (1994) Information structure and sentence form: topic, focus, and the mental representation of discourse referents. Cambridge: Cambridge University Press.

Matić, Dejan, Rik van Gijn, and Robert D. Van Valin, Jr. (2014) “Information structure and reference tracking in complex sentences: an overview". In Rik van Gijn, Jeremy Hammond, Dejan Matić, Saskia van Putten, and Ana Vilacy Galucio, eds. Information structure and reference tracking in complex sentences, 1-42. Amsterdam and Philadelphia: John Benjamins.

Nikolaeva, Irina (2005) “Agreement and situation construal: evidence from Ob-Ugric and Samoyed languages". In Marie Madeleine Jocelyne Fernandez-Vest, ed. Les langues ouraliennes aujourd'hui: approche linguistique et cognitive. The Uralic languages today: a linguistic and cognitive approach, 533-546. Paris: Bibl. de l'École des Hautes Études.

Nikolaeva, Irina (2014) A grammar of Tundra Nenets. Berlin and Boston: De Gruyter.

Nikolaeva, Irina, András Bárány, and Oliver Bond (2019) “Towards a typology of prominent internal possessors". In András Bárány, Oliver Bond, and Irina Nikolaeva, eds. Prominent internal possessors, 1-38. Oxford: Oxford University Press.

Ovsjannikova, Marija Aleksandrovna (2011) "Topikalizacija posessora v lesnom dialekte ėneckogo jazyka”. Acta Linguistica Petropolitana. Trudy Instituta lingvisticheskix issledovanij RAN 7, 3, 153-159. Sankt-Petersburg: Nauka.

Ovsjannikova, Marija Aleksandrovna (2018) "Kodirovanie učastnikov pri dvuxmestnyx predikatax v lesnom dialekte ėneckogo jazyka". Uralo-altajskie issledovanija 28, $1,50-69$.

Ovsjannikova, Maria and Sergey Say (2014) "Between predicative and attributive possession in Bashkir". In Pirkko Suihkonen and Linsay J. Whaley, eds. On diversity and complexity of languages spoken in Europe and North and Central Asia, 175201. Amsterdam and Philadelphia: John Benjamins. 
Payne, Doris L. and Immanuel Barshi, eds. (1999) External possession. Amsterdam and Philadelphia: John Benjamins.

Seiler, Hansjakob (1983) Possession as an operational dimension of language. Tübingen: Gunter Narr Verlag.

Shibatani, Masayoshi (2001) "Non-canonical constructions in Japanese". In Alexandra Y. Aikhenvald, Robert M. W. Dixon, and Masayuki Onishi, eds. Non-canonical marking of subjects and objects, 307-354. Amsterdam and Philadelphia: John Benjamins.

Siegl, Florian (2013) Materials on Forest Enets, an indigenous language of Northern Siberia. Helsinki: Finno-Ugrian Society.

Siegl, Florian (2015) "The structure of noun phrases with referential PX.2P in Northern Samoyedic". Tomsk Journal LING \& ANTHRO 1, 7, 21-31.

Sorokina, Irina Petrovna (2010) Éneckij jazyk. Sankt-Petersburg: Nauka.

Stassen, Leon (2009) Predicative possession. Oxford: Oxford University Press.

Stassen, Leon (2013) "Predicative possession". In Matthew S. Dryer and Martin Haspelmath, eds. The world atlas of language structures online. Munich: Max Planck Digital Library. Available online at $<\mathrm{http}$ ://wals.info/ $>$. Accessed on 07.01.2019.

Stolz, Thomas and Christel Stolz (2009) "A chapter in marginal possession: on being six(ty) in Europe (and beyond)". In Johannes Helmbrecht, Yoko Nishina, YongMin Shin, Stavros Skopeteas, and Elisabeth Verhoeven, eds. Form and function in language research: papers in honour of Christian Lehmann, 69-90. Berlin: Mouton de Gruyter.

Šluinskij, Andrej Boleslavovič (2010) “'Kontrastivnye' glagolnye okončanija v lesnom dialekte ėneckogo jazyka". In Svetlana Igorevna Burkova, ed. Materialy 3-j meždunarodnoj konferencii po samodistike, 279-291. Novosibirsk: Ljubava.

Tereščenko, Natal'ja Mitrofanovna (1962) “O vyraženii posessivnyx otnošenij v samodijskix jazykax”. In Boris Aleksandrovič Serebrennikov, Vasilij Il’ič Lytkin, and Klara Jevgen'evna Majtinskaja, eds. Voprosy finno-ugorskogo jazykoznanija, 81-93. Moskva and Leningrad: Izdatel'stvo AN SSSR.

Tereščenko, Natal'ja Mitrofanovna (1966) “Ėneckij jazyk”. In Jazyki narodov SSSR, Vol. 3: Finno-ugorskie i samodijskie jazyki, 438-457. Moskva: Nauka.

Tereščenko, Natal'ja Mitrofanovna (1973) Sintaksis samodijskix jazykov. Leningrad: Nauka.

Wagner-Nagy, Beáta (2011) On the typology of negation in Ob-Ugric and Samoyedic languages. Helsinki: Finno-Ugrian Society.

Wagner-Nagy, Beáta (2014) "Possessive constructions in Nganasan". Tomsk Journal $L I N G \&$ ANTHRO 1, 3, 76-82.

Wagner-Nagy, Beáta (2016) "Existentials, possessives and definiteness in Samoyedic languages”. In Susann Fischer, Tanja Kupisch, and Esther Rinke, eds. Definiteness effects: bilingual, typological and diachronic variation, 213-243. Cambridge: Cambridge Scholars Publishing.

Wagner-Nagy, Beáta (2018) A grammar of Nganasan. Leiden and Boston: Brill. 
Xanina, Ol'ga Vladimirovna and Andrej Boleslavovič Šluinskij (2013) “Jadernye padeži suščestvitelnyx v èneckom jazyke: v poiskax adekvatnogo opisanija”. Lingvističeskij bespredel - 2. Sbornik naučnyx trudov k jubileju A. I. Kuznecovoj, 76-94. Moskva: Izdatel'stvo MGU.

\begin{abstract}
Kokkuvõte. Maria Ovsjannikova: Metsaeenetsi keele obliikvakäändelised ja nimetavakäändelised nominaalsed omajad. Metsaeenetsi keeles eristatakse kaht tüüpi omajakodeeringut: nimetavakäändeline ja obliikvakäändeline. Küsitlemise teel kogutud andmed näitavad, et obliikvakäändeline omaja on osa noomenifraasist, milles omatav esineb põhisõnana, samas kui nimetavakäändelisel omajal on nii eraldatud topikaliseeritud moodustaja kui ka välise omaja tunnused. Selle töö eesmärk on uurida nende omajastrateegiate kasutamist tekstis. Uurin nende distributsiooni omatava süntaktiliste funktsioonide ja semantilise klassi ning predikaadi tüübi mõttes. Nimetavakäändeline omajakodeering näib olevat tugevalt seotud konstruktsioonidega, mis kirjeldavad 1) erinevat tüüpi omajasuhteid (omamise väljendamine predikaadi kaudu, omaja vanuse ja nime väljendamine) ja 2) omaja kehaosade olukorda. Obliikvakäändelised omajad toimivad tüüpiliselt referentsiaalsete ankrutena ja ei ole konstruktsioonisemantika poolt nii määratletud, täpsemalt on nad sagedasemad siis, kui omatav on agentiivne ja elus.
\end{abstract}

Märksõnad: omamine, topik, predikatiivne omajakonstruktsioon, eenetsi keel, väline omaja, nimetavakäändeline omaja

\title{
Аннотация. Мария Овсянникова: Косвенное и номинативное коди- рование именного посессора в лесном диалекте энецкого языка. В
} лесном диалекте энецкого языка выделяются два способа кодирования посессора: косвенная форма и форма номинатива. Данные элицитации показывают, что посессор в косвенной форме является частью именной группы обладаемого, в то время как номинативный посессор обладает сходством как с вынесенным топиком, так и с внешним посессором. Основное внимание уделяется употреблению двух способов кодирования в текстах. Рассматривается их распределение в зависимости от синтаксической позиции и семантического класса обладаемого, а также от типа предиката. Номинативное кодирование связано прежде всего с конструкциями, которые описывают 1) различные посессивные отношения (такими как собственно предикативная посессивная конструкция и конструкции, называющие возраст и имя посессора), а также 2) состояние части тела посессора. Посессор в косвенной форме обычно служит 
98 Maria Ovsjannikova

«референциальным якорем» и менее избирателен к типу конструкции, в частности такое кодирование чаще встречается при агентивном одушевленном обладаемом.

Ключевые слова: посессивность, топикальность, предикативная посессивная конструкция, энецкий язык, внешний посессор, номинативный посессор 